This article was downloaded by: [UNISA University of South Africa]

On: 12 July 2010

Access details: Access Details: [subscription number 780765662]

Publisher Routledge

Informa Ltd Registered in England and Wales Registered Number: 1072954 Registered office: Mortimer House, 3741 Mortimer Street, London W1T 3JH, UK

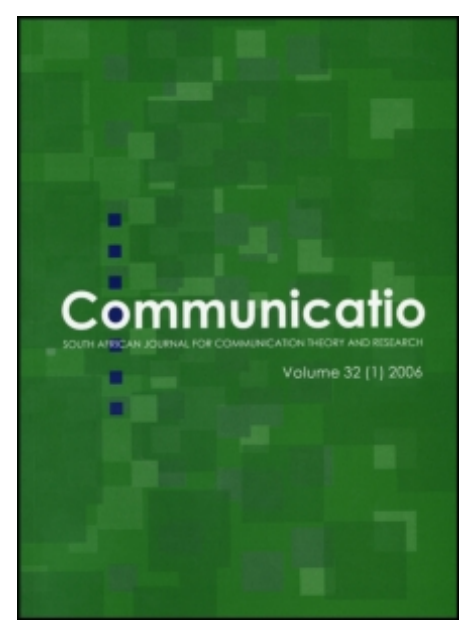

\title{
Communicatio
}

Publication details, including instructions for authors and subscription information:

http://www.informaworld.com/smpp/title content=t777285706

\section{A conceptual framework of corporate online communication: A marketing public relations (MPR) perspective}

Charmaine du Plessis; George Angelopulo; Danie du Plessis

To cite this Article Plessis, Charmaine du, Angelopulo, George and Plessis, Danie du(2006) 'A conceptual framework of corporate online communication: A marketing public relations (MPR) perspective', Communicatio, 32 : 2, 241 - 263

To link to this Article: DOI: $10.1080 / 02500160608537972$

URL: http://dx.doi.org/10.1080/02500160608537972

\section{PLEASE SCROLL DOWN FOR ARTICLE}

Full terms and conditions of use: http://www.informaworld.com/terms-and-conditions-of-access.pdf

This article may be used for research, teaching and private study purposes. Any substantial or systematic reproduction, re-distribution, re-selling, loan or sub-licensing, systematic supply or distribution in any form to anyone is expressly forbidden.

The publisher does not give any warranty express or implied or make any representation that the contents will be complete or accurate or up to date. The accuracy of any instructions, formulae and drug doses should be independently verified with primary sources. The publisher shall not be liable for any loss, actions, claims, proceedings, demand or costs or damages whatsoever or howsoever caused arising directly or indirectly in connection with or arising out of the use of this material. 


\title{
A conceptual framework of corporate online communication: A marketing public relations (MPR) perspective
}

\author{
Charmaine du Plessis, George Angelopulo and Danie du Plessis
}

\begin{abstract}
This study identifies attributes that are perceived by online communicators as contributing to the effectiveness of corporate online communication. A marketing public relations (MPR) perspective is applied to assess the contribution of credibility, trust and long-term relationships to effective corporate online communication.

$Q$ methodology is used as the research method and $Q$ sorting as the means of data collection. Credibility, trust, long-term relationships and their composite factors are tested among 20 communicators and 20 receivers of corporate online communication. The participants' sortings of statements are first compared by means of $Q$ factor analysis and then analysed. Four factors are ultimately identified that are perceived to contribute to effective corporate online communication by communicators and receivers: trust, responsibility, efficiency and meaningful relationships.
\end{abstract}

Keywords: corporate online communication; corporate marketing public relations; credibility; factor; factor analysis; Internet; long-term relationships; MPR; marketing communications; organisational communication; $Q$ methodology; trust; Website; World Wide Web

\section{. Introduction}

he aim of the study was to test the perceived contribution of three factors (i.e. credibility, ust and long-term relationships) and their composite elements to the success of corporate nline communication, as seen from the perspective of online communicators. The main search problem was the identification of dominant factors that are perceived to etermine the effectiveness of corporate online communication.

he Internet has become an integral part of organisational communication, and has proved , be a medium with many opportunities for both the marketing and public relations isciplines. Since the commercialisation of the Internet in the early $1990 \mathrm{~s}$, its development as impacted on all aspects of organisational communication. In South Africa marketers nd public relations practitioners began the extensive utilisation of corporate online ommunication from about 1995.

orporate online communication refers to online communication by an organisation using computer and a specific Internet resource to employ online actions to attain specific oals. Primary benefits of online communication are the immediacy and flexibility that haracterise the online environment. The corporate Website in particular is used by these vo disciplines to practise corporate online communication to attain specific objectives.

harmaine du Plessis is a Senior Lecturer and George Angelopulo and Danie du Piessis are Associate Professors in the epartment of Communication Science, University of South Africa. dplestc@unisa.ac.za 
Many organisations have established corporate Websites to create a greater awareness of their products and services, to enhance their corporate image and identity, while others use online communicators as an extension of their commercial activities.

In spite of the contribution of corporate online communication to the success of many organisations, research affirms the lack of a theoretical foundation in the practise of corporate online communication, particularly in the context of selling the organisation's products and services. Merrilees and Fry (2003) have found that the trust and credibility built up through an organisation's operations do not necessarily carry over to its online activities. Middleberg and Ross (1999) found that the majority of journalists remain sceptical about most sites. In a survey of newspaper and magazine editors in the United States of America (US) in 1999 only trade association sites were found to be credible (Jarvis 2000). To be perceived as credible, Website content requires that the hosting organisation also be considered credible, which is confirmed by a study by Eastin (2001). This study indicates that the source's expertise and knowledge of content affect online users' perception of the credibility of its online communication. The perceived dynamism of the organisation contributes to the credibility of the organisation's corporate online communication. Perry and Bodkin's (2000) study of the Internet as a marketing communication tool reveals that most organisations with an online presence do not make the most of their corporate online communication. According to Breitenbach and van Doren (1998), many organisations do not know how to practise corporate online communication in a way that forges long-term relationships with their online customers.

Research by Hoffman, Novak and Peralta (1998) indicates that lack of trust in e-commerce is a result of online consumers' perceived lack of control over the access others have to their personal information during the online navigation process. Their research indicates that nearly 63 per cent of consumers decline to provide personal information to Websites because they do not trust those collecting the data. Online consumers also do not trust most organisations enough to engage in online exchanges with them. They suggest that trust will be best achieved by allowing the balance of power to shift towards more cooperative interaction between the online business and its customers.

Online customers still have concerns about issues such as the trustworthiness of Websites and the people running them, and the safety of transmitting sensitive information (Boyd 2002). One of the world's most successful online public sales sites, e-bay.com, is extremely successful even though online customers do not see or inspect the goods on auction. A case study by Boyd (2002) indicates that e-bay communicates safe online transactions within 'an e-bay community' and also provides online customers with control over their online experience. The success of e-bay illustrates that online messages should be communicated in an environment of customer privacy, secure transaction, error-free billing and availability of merchandise. Online customers should also be able to monitor the status of their orders and online account details. A study by Karayanni and Baltas 
(2003) on Website characteristics partially supports their hypothesis that transferring control of information flows to the user of information can be related to higher industrial sales achieved through the Internet.

More emphasis is placed in the literature on the establishment of long-term online relationships than on enhancing online credibility and trust. This is because many organisations still struggle to retain their online customers by not engaging in a long-term relationship with them. Theorists therefore increasingly argue in favour of corporate Websites that facilitate meaningful business and interaction with the organisation. The online user should consider his or her online visit as meaningful and worthwhile, because he or she is involved in the communication experience (Sterne 2000). According to Geissler (2001), interactive communication is the primary integrative element in building and managing brand relationships. Burke (2001) points out that the Internet can achieve such relationships because it offers opportunities for both customer development and relationship building.

Online customers have high expectations of new technology. According to Johannessen, Olaissen and Olsen (1999), customers expect organisations to use information technology to enhance service quality, and to generate greater satisfaction with the organisation's products and services. Many organisations have since experienced the ease with which they lose online customers because of poor customer service and feedback. Bickerton, Bickerton and Pardesi (2000) regard the primary motivators for online shopping to be saving money, time, travelling and a wider choice of products for the customer. However, research by various organisations indicates that the standard of online customer service is still poor, making it difficult for organisations to retain their online customers (Treminio 2000-2001).

\section{Theoretical and conceptual foundations of the study}

Marketing public relations (MPR) is an integrated cross-disciplinary approach with a strong product and service focus that has been practised for many years (Harris 1991). According to the literature, MPR offers three main benefits, namely (1) greater credibility, (2) more trust and (3) the establishment of long-term relationships (Guth and Marsh 2000; Harris 1993; 1998; Marken 1995). Credibility, trust and long-term relationships are, however, universal and multidimensional concepts applicable to all instances of communication in the organisation. They may have different meanings in different contexts. Theorists also have various perspectives on the meaning of these concepts. Although the concepts of credibility, trust and long-term relationships are not universally used in the same way in the literature, there is some consensus on essential differences and meaning (see Tables 1 to 7).

The contribution of MPR to the generation of credibility, trust and the establishment of long-term relationships forms the basis from which the discourse on corporate online communication was derived for the empirical part of this study. 
Du Plessis $(2005,53)$ defines MPR as: 'an integrated and interactive way of planning, executing and evaluating communication in order to enhance credibility, trust and longterm relationships with the organisation's stakeholders and customers in the selling of its products and services'.

MPR activities include both marketing and public relations techniques and tactics that enhance the selling of an organisation's products and services. Although some of these activities are typical of public relations, they are applied in the context of selling products and services. MPR activities are directed at abundant two-way interaction between the organisation and its various stakeholders and customers, at community involvement and at making the organisation's products and services more visible (Harris 1991; 1998). Much of the literature on MPR hypothesises that when organisations use MPR effectively to promote their products and services, credibility, trust and long-term relationships are enhanced. MPR includes techniques and tactics from both the marketing and public relations disciplines. The organisation can benefit from long-term relationships with its customers as well as more credibility and greater trust in the sale of its products and services.

MPR enhances the organisation's credibility by ensuring responsible action, making use of media endorsement, providing useful information and being socially responsible (Guth and Marsh 2000, Harris 1991; Kitchen 1996; Kitchen and Papasolomou in Kitchen 1999; Marks 2002; Strenski 1991; Wells, Burnett and Moriarty 2003; Wells and Spinks 1999).

MPR enhances trust in the organisation by creating familiarity with the organisation and its brands, and making the organisation more accessible and visible (Beavers-Moss 2001; Harris 1991; Harris 1998; Kitchen and Papasolomou 1999 in Kitchen 1999).

MPR contributes to the establishment of long-term relationships by enabling feedback, one-to-one interaction, customer service and the differentiation of products and services according to customer needs (Harris 1991; Harris 1998; Marken 1995).

An extensive literature review identified the levels for the three categories of the structured Q sample (see Table 8). The levels of the structured Q sample were selected according to the dimensions of the three categories and their relevance to MPR (see Tables 1 to 7). Because the concept of credibility is multidimensional, the following allencompassing levels were selected for the structured Q sample, on the basis of the various dimensions of the concept of credibility and their relevance to MPR (see Table 2):

- History

- Perception

- Social responsibility.

The above levels were selected because they include the different dimensions of the category of credibility as elucidated by Table 1 . 
Table 1: The dimensions included in the all-encompassing levels of the category of credibility

\begin{tabular}{|l|l|}
\hline All-encompassing level & Dimensions contained in this level \\
\hline History & $\begin{array}{l}\text { - Past actions can predict future behaviour } \\
\text { - Trustworthiness } \\
\text { - Behavioural integrity }\end{array}$ \\
\hline Perception & $\begin{array}{l}\text { - Level of expertise } \\
\text { - Composure } \\
\text { - Dynamism } \\
\text { - Sociability } \\
\text { - Extroversion } \\
\text { - Similarity to the audience } \\
\text { - Use of media by sources } \\
\text { - Brand }\end{array}$ \\
\hline Social responsibility & - Believability of intentions \\
\hline
\end{tabular}

Table 2 breaks down the dimensions of the concept of credibility and indicates its relevance to MPR.

Table 2: Dimensions of the concept of credibility

\begin{tabular}{|l|l|}
\hline Dimension & Description \\
\hline Believability of intentions & $\begin{array}{l}\text { The organisation's good intention in terms } \\
\text { of its products and services is illustrated by } \\
\text { its continuous community involvement and } \\
\text { participation. }\end{array}$ \\
\hline Behavioural integrity & $\begin{array}{l}\text { Because of media endorsement and the } \\
\text { organisation's community involvement, its } \\
\text { products and services are more believable. } \\
\text { The organisation is perceived as keeping its } \\
\text { promises in this regard. }\end{array}$ \\
\hline Past actions can predict future behaviour & $\begin{array}{l}\text { The history and actions of the organisation } \\
\text { are an indication of its responsible action } \\
\text { and future behaviour in terms of its pro- } \\
\text { duct(s) and/or service(s). }\end{array}$ \\
\hline Brand & $\begin{array}{l}\text { The organisation's products and services are } \\
\text { regarded as credible because of its visibility, } \\
\text { media endorsement and involvement in the } \\
\text { community. The organisation is also valued for } \\
\text { its expertise, trustworthiness and likeability with } \\
\text { regard to its product(s) and/or service(s). }\end{array}$ \\
\hline
\end{tabular}

Sources: Herbig and Milewicz $(1995,6)$; Simons $(2002,19)$ 
Table 3 summarises the dimensions of the concept of source credibility and their relevance to MPR.

Table 3: Dimensions of the concept of source credibility

\begin{tabular}{|l|l|}
\hline Dimension & Description \\
\hline Level of expertise & $\begin{array}{l}\text { The organisation's level of expertise is illustrated by its } \\
\text { brand, culture, products and services and efficient mes- } \\
\text { sages in this regard. }\end{array}$ \\
\hline Composure & $\begin{array}{l}\text { The organisation's composure is evident in its activities, } \\
\text { history and media endorsement in terms of its product(s) } \\
\text { and/or service(s). }\end{array}$ \\
\hline Trustworthiness & $\begin{array}{l}\text { The social responsibility and the good intentions of the } \\
\text { organisation are indicative of its trustworthiness in terms of } \\
\text { its product(s) and/or service(s). }\end{array}$ \\
\hline Sociability & $\begin{array}{l}\text { The dynamism of the organisation is evident in its expert } \\
\text { personnel with regard to its product(s) and/or service(s). }\end{array}$ \\
\hline Extroversion & $\begin{array}{l}\text { The organisation's sociability is evident in its actions, special } \\
\text { events, as well as community and environmental involve- } \\
\text { ment in terms of its product(s) and/or service(s). }\end{array}$ \\
\hline Similarity to audience & $\begin{array}{l}\text { The organisation's extroversion is evident in its history, } \\
\text { actions and media endorsement in terms of its product(s) } \\
\text { and/or service(s). }\end{array}$ \\
\hline $\begin{array}{l}\text { The organisation's similarity to the audience is evident in its } \\
\text { profile, history and useful information in terms of its } \\
\text { product(s) and/or service(s). }\end{array}$ \\
\hline $\begin{array}{l}\text { The organisation's products and services are accepted } \\
\text { because it is perceived as a credible source. The way the } \\
\text { organisation uses the media affects perceptions of its } \\
\text { credibility in terms of, say, its level of expertise, composure, } \\
\text { trustworthiness, dynamism, sociability, extroversion and } \\
\text { similarity to the audience (with regard to its product(s) } \\
\text { and/or service(s). }\end{array}$ \\
\hline
\end{tabular}

Source: Ferguson $(1999,131-138$ )

The concept of trust is also multidimensional. Therefore, on the basis of the various dimensions of the concept of trust and their relevance to MPR (see Table 5), the following all-encompassing levels are selected for the structured $Q$ sample:

- Accountability

- Concreteness

- Association. 
The above levels were selected because they include all the different dimensions of the category of trust elucidated in Table 4.

Table 4: The dimensions included in the all-encompassing levels of the category of trust

\begin{tabular}{|l|l|}
\hline All-encompassing level & Dimensions contained in this level \\
\hline Accountability & $\begin{array}{l}\text { - No sense of risk } \\
\text { - Predictability } \\
\text { - Intentions or motives } \\
\text { - Consistency } \\
\text { - Character } \\
\text { - Honesty } \\
\text { - Responsibility }\end{array}$ \\
\hline Concreteness & $\begin{array}{l}\text { - Confidence } \\
\text { - Motivation to lie } \\
\text { - Integrity } \\
\text { - Openness of management } \\
\text { - Respect } \\
\text { - Faith } \\
\text { - Acceptance } \\
\text { - Security }\end{array}$ \\
\hline Association & $\begin{array}{l}\text { - Ability } \\
\text { - Expertness } \\
\text { - Competence } \\
\text { - Benevolence } \\
\text { - Altruism } \\
\text { - Congruence } \\
\text { - Loyalty } \\
\text { - Fairness } \\
\text { - Liking } \\
\text { - Dependability }\end{array}$ \\
\hline
\end{tabular}

Table 5 summarises the dimensions of the concept of trust and their relevance to MPR.

Table 5: Dimensions of the concept of trust

\begin{tabular}{|l|l|}
\hline Dimension & Description \\
\hline No sense of risk & $\begin{array}{l}\text { When the organisation breeds trust in its } \\
\text { products and services through visibility, } \\
\text { response and commitment, consumers will } \\
\text { experience a feeling of no sense of risk. }\end{array}$ \\
\hline Confidence & $\begin{array}{l}\text { Because the organisation's products and } \\
\text { services are known, consumers have con- } \\
\text { fidence about their dealings with it. }\end{array}$ \\
\hline
\end{tabular}




\begin{tabular}{|c|c|}
\hline Dimension & Description \\
\hline Predictability & $\begin{array}{l}\text { Because the organisation is visible and } \\
\text { known by its customers/publics, they can } \\
\text { predict its actions in terms of their dealings } \\
\text { with its products and services. }\end{array}$ \\
\hline Ability & $\begin{array}{l}\text { Because of the organisation's visibility and } \\
\text { strong financial position, its customers/pub- } \\
\text { lics trust its ability in terms of its products and } \\
\text { services. }\end{array}$ \\
\hline Expertness & $\begin{array}{l}\text { Because the organisation and its staff are } \\
\text { visible, its customers/publics trust its expert- } \\
\text { ness in terms of its products and services. }\end{array}$ \\
\hline Competence & $\begin{array}{l}\text { The organisation is regarded as competent } \\
\text { in terms of its products and services be- } \\
\text { cause of its visibility. }\end{array}$ \\
\hline Intentions or motives & $\begin{array}{l}\text { When the organisation breeds trust in its } \\
\text { products and services through visible ac- } \\
\text { tions and direct involvement, consumers } \\
\text { will be convinced of its good intentions or } \\
\text { motives. }\end{array}$ \\
\hline Benevolence & $\begin{array}{l}\text { The organisation's direct involvement with } \\
\text { its customers in terms of its products and } \\
\text { services is indicative of its benevolence. }\end{array}$ \\
\hline Motivation to lie & $\begin{array}{l}\text { Because the organisation is visible and } \\
\text { known by its customers/publics, they can } \\
\text { predict its actions in terms of its honest } \\
\text { dealings in its products and services. }\end{array}$ \\
\hline Altruism & $\begin{array}{l}\text { The organisation's corporate identity cre- } \\
\text { ates a feeling of kindness in terms of its } \\
\text { products and services. }\end{array}$ \\
\hline Loyalty & $\begin{array}{l}\text { The organisation's direct involvement with, } \\
\text { and commitment to, its customers generates } \\
\text { loyalty towards its products and services. }\end{array}$ \\
\hline Integrity & $\begin{array}{l}\text { The organisation's direct involvement with, } \\
\text { consumers and its responsible conduct are } \\
\text { indicative of its integrity with regard to its } \\
\text { products and services. }\end{array}$ \\
\hline Congruence & $\begin{array}{l}\text { Because of the visibility of the organisation } \\
\text { and its commitment to its customers, cus- } \\
\text { tomers can relate to its products and } \\
\text { services. }\end{array}$ \\
\hline
\end{tabular}




\begin{tabular}{|c|c|}
\hline Dimension & Description \\
\hline Consistency & $\begin{array}{l}\text { Because the organisation is visible and } \\
\text { known by its customers/publics, they can } \\
\text { predict its consistent actions in terms of their } \\
\text { dealings with its products and services. }\end{array}$ \\
\hline Fairness & $\begin{array}{l}\text { Because the organisation is visible and } \\
\text { known by its customers/publics, they can } \\
\text { predict its fairness in terms of their dealings } \\
\text { with its products and services. }\end{array}$ \\
\hline Character & $\begin{array}{l}\text { The organisation's corporate identity is } \\
\text { indicative of its truthfulness in terms of its } \\
\text { products and services. }\end{array}$ \\
\hline Openness of management & $\begin{array}{l}\text { Because of the organisation's visibility in } \\
\text { terms of its products and services, its } \\
\text { management is known and respected. }\end{array}$ \\
\hline Liking & $\begin{array}{l}\text { Because the organisation is visible and } \\
\text { known by its customers/publics, they like } \\
\text { conducting business with it. }\end{array}$ \\
\hline Respect & $\begin{array}{l}\text { Because the organisation is visible and } \\
\text { known by its customers/publics, they have } \\
\text { respect for and value its products and } \\
\text { services. }\end{array}$ \\
\hline Faith & $\begin{array}{l}\text { Because the organisation is visible and } \\
\text { known by its customers/publics, they have } \\
\text { faith in its products and services. }\end{array}$ \\
\hline Acceptance & $\begin{array}{l}\text { Because the organisation is visible and } \\
\text { known by its customers/publics, they ac- } \\
\text { cept its products and services. }\end{array}$ \\
\hline Security & $\begin{array}{l}\text { When the organisation breeds trust in its } \\
\text { products and services through visible ac- } \\
\text { tions, commitment and direct involvement } \\
\text { consumers will experience a feeling of } \\
\text { security in their dealings with it. }\end{array}$ \\
\hline Honesty & $\begin{array}{l}\text { Because the organisation is visible and } \\
\text { known by its customers/publics, they can } \\
\text { predict its actions in terms of its honest } \\
\text { dealings with its products and services. }\end{array}$ \\
\hline Dependability & $\begin{array}{l}\text { Because the organisation is committed to } \\
\text { its customers, they feel that they can } \\
\text { depend on it when it comes to their deal- } \\
\text { ings with its products and services. }\end{array}$ \\
\hline
\end{tabular}




\begin{tabular}{|l|l|}
\hline Dimension & Description \\
\hline Responsibility & $\begin{array}{l}\text { Because of the openness of the organisa- } \\
\text { tion, customers perceive it as being re- } \\
\text { sponsible in terms of its products and } \\
\text { services. }\end{array}$ \\
\hline Accountability & $\begin{array}{l}\text { The provision of reliable information to } \\
\text { stakeholders and society is indicative of the } \\
\text { organisation's accountability in terms of its } \\
\text { products and services. }\end{array}$ \\
\hline
\end{tabular}

Sources: Delgado-Ballester and Munuera-Aleman (2001); Svensson (2001); Swift (2001)

The concept of long-term relationships is also multidimensional. Therefore, the following all-encompassing levels are selected for the structured $Q$ sample on the basis of the various dimensions of the concept of long-term relationships and their relevance to MPR (see table 7).

- Personal interaction

- Expectation.

The above levels were selected because they include the different dimensions of the category of long-term relationships as elucidated in Table 6.

Table 6: The dimensions included in the all-encompassing levels of the category of longterm relationships

\begin{tabular}{|l|l|}
\hline All-encompassing level & Dimensions contained in this level \\
\hline Personal interaction & $\begin{array}{l}\text { - Developing customer networks } \\
\text { - Customer service } \\
\text { - Personalisation } \\
\text { Interaction }\end{array}$ \\
\hline Expectation & $\begin{array}{l}\text { - Fulfilling the needs of the customer } \\
\text { - Commitment } \\
\text { - Differentiated products and services }\end{array}$ \\
\hline
\end{tabular}


Table 7 summarises the dimensions of the concept of long-term relationships and their relevance to MPR.

Table 7: Dimensions of the concept of long-term relationships

\begin{tabular}{|l|l|}
\hline Dimension & Description \\
\hline Fulfilling the needs of the customer & $\begin{array}{l}\text { Constant feedback and interaction be- } \\
\text { tween the organisation and its various } \\
\text { customers/publics can result in better } \\
\text { knowledge on how to better fulfil custo- } \\
\text { mers' needs in terms of it product(s) and/or } \\
\text { service(s). }\end{array}$ \\
\hline Development of customer networks & $\begin{array}{l}\text { Constant feedback and interaction be- } \\
\text { tween the organisation and its various } \\
\text { customers/publics with regard to its pro- } \\
\text { ducts and services can result in the building } \\
\text { up of customer databases and continuous } \\
\text { contact with the organisation's customers. }\end{array}$ \\
\hline Customer service & $\begin{array}{l}\text { Interaction and response to customers' } \\
\text { needs with regard to the organisation's } \\
\text { products and services are indicative of } \\
\text { effective customer service. }\end{array}$ \\
\hline Commitment & $\begin{array}{l}\text { The organisation's commitment to its cus- } \\
\text { tomers in terms of its products and services } \\
\text { is expressed in its quality products, services } \\
\text { and interaction. }\end{array}$ \\
\hline Interaction & $\begin{array}{l}\text { A set of one-to-one relationships in which } \\
\text { some customers are targeted individually } \\
\text { with regard to the organisation's products } \\
\text { and services can build an enduring rela- } \\
\text { tionship with the organisation. }\end{array}$ \\
\hline $\begin{array}{l}\text { Constant feedback and interaction be- } \\
\text { tween the organisation and its various } \\
\text { customers/publics, including the commu- } \\
\text { nity in terms of its products and services, } \\
\text { can result in enhanced knowledge on how } \\
\text { to better fulfil customers' needs and es- } \\
\text { tablish a favourable reputation. }\end{array}$ \\
\hline $\begin{array}{l}\text { The needs of the organisation's customers } \\
\text { are fulfilled through products and services } \\
\text { with a difference, which will retain them. }\end{array}$ \\
\hline
\end{tabular}

Sources: Goldsmith (1999); Gummesson in Kandampully and Duddy (1999); Jüttner and Wehrli (1994); Wells and Spinks (1999) 
Corporate online communication from an MPR perspective constitutes the use of appropriate Internet resources as well as integrated corporate online communication techniques to enhance credibility and trust and to establish long-term relationships with the organisation's online customers with regard to the selling of its products and services.

\section{Methodology}

This study uses $Q$ methodology to identify factors for effective corporate online communication. Q methodology permits the systematic study of subjectivity and the communication of subjective perceptions in a discourse on a specific topic. Central to its investigative procedure is the adoption of the participants' point of view (Goldman 1999). Definitions of viewpoints (subjective perceptions) are those of participants themselves, and not those generated by the researcher (McKeown and Thomas 1988).

The following three questions underlie a Q study (Stricklin and Almeida 1999):

1. What is the range of communicated ideas in a particular discourse?

2. What are the prevalent variations in it?

3. How do these variations logically relate to each other?

A Q study generally follows a sequence of five phases. The researcher first collects a concourse from people involved in it and then selects a sample of statements representative of the range of communicated ideas in the discourse. A concourse involves ordinary conversation, commentary and discourse about everyday life, not restricted to words, but including collections of paintings, artworks, photographs and even musical selections. Participants are selected from the people involved in the discourse. They are asked to sort statements in their perceived order of importance on a large board in a process known as Q sorting. The participants' sorts are then compared by means of Q factor analysis. Finally, the results are analysed to establish trends in the discourse (Stricklin and Almeida 1999).

\subsection{Structure of the $Q$ sample and statements}

It is impossible to administer an entire concourse, which could extend to hundreds of statements containing opinions on the topic under consideration (Brown 1980). It is therefore necessary to draw a sample of statements in what is known as a ' $Q$ sample'. The researcher thus faces the challenge of compiling statements that are more or less representative of the concourse (Brown 1980).

Once statements have been gathered from primary and secondary sources in the widest sense, these are organised, analysed and logically presented. An effective way of doing this is by grouping the statements into theoretical categories in a structured $Q$ sample that is more or less representative of the broad concourse (Brown 1980). 
In the structured Q sample used in this study statements are organised and specified in terms of three categories: credibility, trust and long-term relationships. The study uses a $3 \times 3 \times 2$ factorial design. Credibility is subdivided into three levels, trust into three levels, and long-term relationships into two levels. Each level comprises three statements, giving a total of 54 statements.

Following the study by Steelman and Maguire (1999), the number of statements per factor reflects the relative importance of each topic in the literature: in this study 14 statements are selected for credibility, 18 for trust and 22 for long-term relationships.

Table 8 indicates the structure of the $\mathrm{Q}$ sample in this study.

Table 8: The structure of the $Q$ sample in this study

\begin{tabular}{|l|l|c|}
\hline Categories & Levels & No. of levels \\
\hline Credibility & $\begin{array}{l}\text { (a) History } \\
\text { (b) Perception } \\
\text { (c) Social responsibility }\end{array}$ & 3 \\
\hline Trust & $\begin{array}{l}\text { (d) Accountability } \\
\text { (e) Concreteness } \\
\text { (f) Association }\end{array}$ & 3 \\
\hline Long-term relationships & $\begin{array}{l}\text { (g) Personal interaction } \\
\text { (h) Expectation }\end{array}$ & 2 \\
\hline
\end{tabular}

Individual statements were printed on ' $\mathrm{Q}$ sort cards' and pretested to ensure clarity and general comparability. There are roughly equal numbers of positive and negative statements.

The cards comprised statements of the following:

\section{Online credibility}

Information on the organisation's activities on the Website increases familiarity with the organisation (Breitenbach and van Doren 1998); an associated 'virtual library' makes the organisation's Website a valuable resource (Burke 2001); the corporate Website should contain information about any charitable activities in which the organisation is involved (Breitenbach and van Doren 1998; Rowley 1998); and information about any community efforts in which the organisation is involved should also be included on the Website (Breitenbach and van Doren 1998). The corporate Website should contain information about any environmental projects in which the organisation is involved (Breitenbach and van Doren 1998); the Website should include a community bulletin board where non profit organisations can publicise events related to the organisation's activities free of charge (Burke 2001); and placement of the organisation's history on its Website increases the believability of the claims related to its operations (Breitenbach and van Doren 1998). 
Information about the organisation's culture should be included on the Website (Karayanni and Baltas 2003); a media section with access to the organisation's media releases should be included (Hurme 2001); and this section should include media coverage on the organisation from other sources as well (Hurme 2001). Users appreciate an educational section on the best way to use a particular product organisation (Breitenbach and van Doren 1998; Burke 2001), while a section on the organisation's special events is also necessary (Breitenbach and van Doren 1998). Furthermore, information about the organisation's products and services must be easily accessible (Burke 2001; Nielsen 2001), while content management software coordinates messages (Geissler 2001).

\section{Online trust}

Multimedia increases a corporate Website's interactivity (Karayanni and Baltas 2003), while the reflection of the organisation's corporate identity creates a feeling of understanding (Karayanni and Baltas 2003). Information about the organisation's financial position (investors' relations section) is important (Karayanni and Baltas 2003); and text chat software for online communication is necessary with an organisational representative (Treminio 2000-2001). It is important for prices to be published (Burke 2001; Dilger 2000).

With regard to security, users want to pay for items via a secured system (Bickerton et al. 2000); there must be a statement that transactions are secure (Merrilees and Fry 2003); the corporate Website must guarantee customer privacy (Merrilees and Fry 2003); there must be a guarantee that merchandise is available at the time of the order (Merrilees and Fry 2003); there must be assurance of service support by the organisation (Markette 2001) and there must be assurance of error-free billing (Merrilees and Fry 2003). Customers should also be able to monitor the status of their orders (Dilger 2000; LaMonica 1999; Sterne 2000 ) and must be able to access the status of their orders at any given time (Sterne 2000). Adequate access to customers' online account details is necessary (Sterne 2000). It is also necessary to inform customers about the means of delivery of their ordered goods (Breitenbach and van Doren 1998).

A contact directory with individual employees' details is desirable (Burke 2001); while a corporate website must also include the organisation's physical address (Burke 2001) and the organisation's contact numbers (Burke 2001).

\section{Online long-ferm relationships}

An e-mail link is essential to enable users to communicate directly with the organisation (Ainscough and Luckett 1996; Bayne 2000), while an online discussion forum for customers is effective (Sterne 2000). An online sales video personalises customer contact (Sterne 2000) and customers generally like an e-mail product newsletter (Sterne 2000). A 
section for frequently asked questions (FAQs) and problems is also beneficial (Bickerton et al. 2000; Breitenbach and van Doren 1998). Regular customers expect Website content to be continually updated (Hurme 2001). Online customers need to be able to navigate logically through the Website (Breitenbach and van Doren 1998; Clyde 2000). A search capability, however, must only be built in if all the relevant keywords produce meaningful results (Bickerton et al. 2000). A standardised response-to-enquiries form assists customers in specifying the exact information they require (Bickerton et al. 2000). A detailed online sales brochure must offer maximum possible choice (Bickerton et al. 2000; Breitenbach and van Doren 1998). Free product samples that can be ordered retain customers (Breitenbach and van Doren 1998). Preprogrammed answers (answerbots) are useful (Sterne 2000). An automatic responder to e-mail is beneficial to the customer (Sterne 2000).

Software that automatically manages customer relationships improves customer service (Sterne 2000). A subscribed mailing list option is essential (Sterne 2000), while an aftersales confirmation e-mail is also needed (Burke 2001; Heinen 1996). The corporate Website must be integrated with other departments in order to manage online relationships with its customers (Law, Lau and Wong 2003).

A guestbook is an effective means of building a customer database (Cunliffe 2000; Sampson 1998). A corporate Website must have exclusive website services for regular customers (Gilbert 1996), for instance, an online members-only magazine attracts other potential customers (Gilbert 1996), while an option to personalise the organisation's Website according to customers' needs increases usability (Hurme 2001). Users want access to links to other sites containing information on the organisation's products and services (Bickerton et al. 2000).

\subsection{Person sample}

In Q methodology, participants are selected from those involved in the discourse under consideration, and are referred to as the person sample. The person sample, unlike the structured Q sample, does not need to be representative of the population. Participants in $\mathrm{Q}$ methodology are sampled theoretically as they are in qualitative research using nonprobability sampling. Participants are purposively selected with the expectation 'that they will hold different points of view on the topic being studied' (Dennis 1986). Large numbers, which are so fundamental to much social research, are relatively unimportant in Q methodology because the emphasis is on the nature of the segments of subjectivity that exist in the discourse, not the people who hold those perceptions (Brown 1991).

Enough participants are required to establish the existence of a factor for the purposes of comparing one factor with another. The results of a $Q$ study are not generalised to the population, but to a specific factor type - a generalisation of a particular perspective (Brown 1980). Generalisations are valid for other persons of the same perspective, for 
instance, for those whose views would lead them to load highly on a factor (Brown 1980). Since factors are 'qualitative categories of thought', additional participants would have virtually no impact on the factor scores (Brown 1991). Dominant categories of perception on the topic are sought, not their representativity within the population.

The study described here was undertaken amongst two separate groups (or person samples): communicators and receivers of corporate online communication.

Twenty 'communicator' participants were selected on the grounds of their compilation or management of corporate online communication for their respective companies. The participants were purposively selected because their companies have established corporate Websites, and these include interactive online activities such as e-commerce.

In order to obtain a variety of perspectives, the 'communicator' participants were selected from companies in a variety of sectors that include life insurance, finance, retail, mobile telephony and banking.

Twenty 'receiver' participants were also selected. These were regular users of the Internet who were familiar with e-commerce, financial online transactions and corporate Websites.

\section{Data analysis}

After the 40 participants in the study had sorted the statements in their perceived order of importance on a large board in a process known as $Q$ sorting (in the presence of the researcher), the PQMethod programme (a public domain programme) was used to analyse the data (www.qmethod.org). The results were analysed by assessing the factor scores, the factor arrays, the distinguishing statements and consensus statements. Once computed, each factor was presented in the form of a factor array - a diagram that represents the perceptual composition of that factor. Factor arrays represent the dominant perceptions of the participants. Q methodology describes overall points of view that blend the composite elements (the statements) into an overall, irreducible gestalt within each factor array (Brown 2003).

\section{Findings}

\subsection{Communicators of corporate online communication}

The assessment amongst communicators of corporate online communication yielded three dominant factors, titled responsible corporate online communication, trust and efficient information.

\section{Factor 1: responsible corporate online communication}

This factor is labelled responsible corporate online communication, because it displays a stronger consideration of reliable and dependable interaction with online customers with 
regard to products and services than the perspectives in factors 2 and 3 . The highly rated statements mirror awareness that corporate online communication must put online customers at ease through assurance and confidence-enhancing interaction. Assurance in this context refers to putting the 'receiver' at ease. These statements deal mainly with online customers' need to know where to find and contact the organisation, their privacy and security, interaction with the organisation and control over their communication with the organisation, for instance, with order tracking information. The factor represents opposition to statements that diminish the customer's confidence in personal and direct contact with the organisation, for instance, by not providing an e-mail address or other contact details. There is a strong awareness that online customers want to feel safe in their dealings with an organisation. This is achieved through the establishment of elements in the organisation's corporate online communication that generate confidence, faith and a sense that the organisation is dependable. The organisation aims to fulfil the needs of its online customers through constant and reliable interaction.

\section{Factor 2: trust}

This factor is labelled trust because it displays a strong emphasis on statements in the category of trust. Statements about the organisation's financial position, the security of transactions, assurance of error-free billing, and information about the means of delivery of ordered goods are more highly rated than in the other factors.

However, as in factor 1 , this factor also rates statements about payment via a secured system and a guarantee of customer privacy highly, but rejects statements that the organisation's physical address must be excluded, its contact numbers be excluded, and that item prices need not be published. This factor also loads highly on three statements in the category long-term relationships, that is, those that deal with the need for updated information, logical navigation and an effective search capability. The highly rated statements mirror awareness that trust is important in order to conduct online business with the organisation. The factor displays opposition to statements suggesting that trust is irrelevant in this regard. It strongly reflects the point of view that online customers wish to feel protected in their online communication and other dealings with an organisation, and that this can be achieved through information and elements in the organisation's corporate online communication that generate respect and faith.

\section{Factor 3: efficient information}

Factor 3 displays sensitivity to the efficient sourcing and presentation of online information on the organisation's products and services. The factor is labelled efficient information because it demonstrates a strong consideration of well-presented and efficient information to the online customer. 
Factor 3 loads much lower on trust than factors 1 and 2, and more on statements in the long-term relationship category. With a few exceptions it also loads relatively low on most statements in the category of credibility. The highly rated statements mirror strong agreement on the usefulness of presentation and the ease of finding information. Apart from the fact that information must be useful, available and up to date, it should also be accessible to the media and retrievable through a virtual library.

This factor displays a strong awareness that corporate online communication needs to be efficient in terms of both presentation and access. The factor supports efficient presentation and the ability to find online information. However, it does not rate contact details of the organisation's employees or exclusive services for loyal online customers as essential and concentrates on the organisation's products and services.

\subsection{Receivers of corporate online communication}

Judgemental rotation yielded the following two dominant factors in the concourse, namely confidence and meaningful relationships.

\section{Factor A: Confidence}

As factor A contains numerous statements related to confidence in the category of trust, it is labelled confidence. It emphasises organisational security, control, openness and visibility. The highly rated statements mirror a need to know that dealings with the organisation pose no risk and that the individual retains control over the online experience in terms of access to account details and the status of online orders. The factor displays opposition to statements that reflect diminished confidence.

The factor displays a strong predisposition towards aspects necessary for the generation of confidence in the organisation. Requirements of assurance dominate, with little emphasis on the establishment of the organisation's credentials or about lasting relationships.

\section{Factor: B: Meaningful relationships}

Although factor B displays elements of credibility, trust and long-term relationships, greater emphasis is placed on credibility than any other factor for both communicators and users of corporate online communication.

This factor is labelled meaningful relationships because it displays a strong concern for perception of the organisation's history, brand, accountability, visibility, expertise and ability in terms of its products and services. This means that for meaningful relationships to be formed, it is expected that the organisation should be perceived to possess expertise, be trustworthy and open, and be dynamic and 'sociable'. The highly rated statements in this factor mirror a need for security, a favourable perception of the organisation and effective customer service. The factor represents an opposition to statements that diminish credibility, trust and long-term relationships. 


\section{Discussion of the findings}

The findings indicate that both the communicators and receivers of corporate online communication perceive trust as the principal component of effective corporate online communication. Realising this, communicators of corporate online communication put more effort into communicating safety and security to enhance confidence than in establishing long-term relationships or earning credibility.

Trust is therefore the only factor that is perceived to be absolutely significant for effective corporate online communication. The findings also indicate that control over their online experience is extremely significant to receivers of corporate online communication. This control is, however, impeded by the communicators of corporate online communication's reluctance to reveal certain information such as employees' contact details.

Credibility and long-term relationships are not perceived to be fundamental to effective corporate online communication as is suggested in the literature. Credibility is not perceived as a single factor for effective corporate online communication, but rather as two different factors: responsible communication and efficient online information. The findings of this study also indicate that neither communicators nor receivers of corporate online communication are particularly concerned about information on community involvement, charitable events, or environmental projects in which the organisation is involved. Communication about social responsibility is not perceived to be significant for effective corporate online communication.

Long-term relationships is a factor that is not perceived to be important on its own, but rather as an amalgamation of certain elements of credibility, trust and long-term relationships. In this context elements of credibility that are deemed important include the company's history and brand, elements of trust that are deemed important include accountability and visibility, and elements of long-term relationships that are deemed important include customer service, feedback and interaction. The emphasis is on creating meaningful relationships rather than on establishing long-term relationships. A relationship is regarded as meaningful when it is perceived to be sincere.

The findings confirm that effective customer service is one of the major difficulties in selling products and services online, as suggested by Burke (2001) and Heinen (1996). While Harris (1998) argues that MPR can be used to communicate new product benefits and uses and in the retention of customers, the findings indicate that this is not necessarily true in an online environment. Communication about differentiated products and services is not perceived to be particularly significant for effective corporate online communication.

It is evident that credibility and long-term relationships are not perceived to be dominant criteria for effective corporate online communication. Three new factors in addition to 
trust are identified as the dominant criteria for effective corporate online communication: responsibility, efficiency and meaningful relationships.

\section{Limitations of the study}

This study has limitations, which are acknowledged as follows:

- Generalisation of the findings can only be related to a factor (perspective) and not to the entire population of South Africa. The findings only indicate trends in the discourse on corporate online communication.

- Q methodology is a small sample research method and subject to criticism.

- The Q sorting process is time-consuming and might have affected participants' responses.

\section{Conclusion}

To be effective, corporate online communication must

- enhance trust by communicating assurance, safety and security in order to create a feeling of confidence

- be responsible through the incorporation of communications that provide receivers with a sense of control over their online experience

- be efficient by presenting clear and effective online information

- create meaningful relationships by allowing interaction, offering good customer service and a favourable perception that in combination generates confidence in the organisation.

Literature still puts more emphasis on the establishment of long-term relationships with online customers than on trust or credibility. The findings of this study suggest that both communicators and receivers of corporate online communication are more concerned about issues related to trust. As the Internet is still an environment that lends itself to abuse and fraud, both receivers and communicators of corporate online communication are more interested in messages that convey safety and assurance. However, the findings of this study suggest that corporate online communication will also be significantly improved if it establishes meaningful relationships and is accountable and well presented.

\section{References}

Ainscough, T. L. and M. G. Luckett. 1996. The Internet for the rest of us: Marketing on the World Wide Web. Journal of Consumer Marketing 13 (2): 36-47.

Bayne, K. M. 2000. The Internet marketing plan: The complete guide to instant Web presence. 2nd ed. New York: Wiley.

Beavers-Moss, D. 2001. PR: The credibility enhancer. Bank Marketing 33 (4), May Business Source Premier. (accessed 13 August 2002). 
Bickerton, P., M. Bickerton and U. Pardesi. 2000. Professional cybermarketing: How to use the Internet to market your goods and services. 2nd ed. Oxford: Butterworth-Heinemann.

Boyd, J. 2002. In community we trust: Online security communication at eBay. 7 (3). Journal of Computer-mediated Communication http://www.ascusc.org/jcmc/ (accessed 12 May 2004).

Breitenbach, C. S. and D. C. van Doren. 1998. Value-added marketing in the digital domain: Enhancing the utility of the Intemet. Journal of Consumer Marketing 15 (6): 558-575.

Brown, S. R. 1980. Political subjectivity: Applications of $Q$ methodology in political science. New Haven: Yale University Press.

Brown, S. R. 1991. Q methodology tutorial. http:/listserv.kent.edu/archives/q-method.html (accessed 12 August 2002).

Brown, S. R. 2003. Pre-flagging in PQMethod. 17 June. http://istserv.kent.edu/archives/q-method. html. (accessed 31 July 2004).

Burke, J. 2001. Relationship aspect marketing: Building customer loyalty in the Internet age. Los Angeles: Silver Lake.

Clyde, L. A. 2000. A strategic planning approach to Website content. The Electronic Library 18(2): $97-108$.

Cunliffe, D. 2000. Developing usable Websites: A review and model. Internet Research: Electronic Networking Applications and Policy 10 (4): 295-307.

Delgado-Ballester, E. and J. L. Munuera-Aleman. 2001. Brand trust in the context of consumer loyalty. European Journal of Marketing. 11 (12): 1238-1258.

Dennis, K. E. 1986. Q methodology: Relevance and application to nursing research. Advances in Nursing Science 8 (3), 6-17 April.

Dilger, K. A. 2000. It's about interaction http://www.manufacturingsystem.com (accessed 20 March 2002).

du Plessis, T. C. 2005. A theoretical framework of corporate online communication: A marketing public relations (MPR) perspective. University of South Africa, Pretoria.

Eastin, M. S. 2001. Credibility assessment of online health information: The effects of source expertise and knowledge of content. Journal of Computer-mediated Communication 6 (4), July. $\mathrm{http} / /$ www.ascusc.org/jcmc/vol6issue4/eastin.html (accessed on 2004.05.12).

Ferguson, S. D. 1999. Communication planning: An integrated approach. Thousand Oaks, Calif: Sage.

Geissler, G. L. 2001. Building customer relationships online: The Website designers' perspective. Journal of Consumer Marketing 18 (6): 488-502.

Gilbert, D. C. 1996. Relationship marketing and airline loyalty schemes. Tourism Management 17 (8): $575-582$.

Goldman, I. 1999. Q methodology as process and context in interpretivism, communication, and psychoanalytic psychotherapy research. The Psychological Record, Fall: 589-604.

Goldsmith, R. E. 1999. The personalised marketplace: Beyond the 4Ps. Marketing Intelligence and Planning 17 (4): $178-185$.

Guth, D. W. and C. Marsh. 2000. Public relations: A values-driven approach. Boston: Allyn and Bacon.

Harris, T. L. 1991. The marketer's guide to PR: How today's companies are using the new public relations to gain a competitive edge. New York: Wiley. 
Harris, T. L. 1998. The ABC's of IMC: Building blocks for integrated marketing communications. In Redefining marketing communication disciplines, ed. A. Gronstedt and L. Siracuse. New York: Advertising Research Foundation.

Heinen, J. 1996. Internet marketing practices. Information Management and Computer Society 4 (5): $7-14$.

Herbig, P. and J. Milewicz. 1995. The relationship of reputation and credibility to brand success. Journal of Consumer Marketing 12 (4): 5-10.

Hoffman, D. L, T. P. Novak and M. Peralta. 1998. Building consumer trust in online environments: the case for information privacy. http:/www.thestandard.com/article/display/0,1151,235,00.html (accessed 25 September 2002).

Hurme, P. 2001. Online PR: Emerging organisational practice. Corporate Communications: An International Journal 6 (2):7 1-75.

Jarvis, S. 2000. How the Internet is changing fundamentals of publicity. Marketing News 34 (15) Business Source Premier Database (accessed 13 August 2002).

Johannessen, J., J. Olaisen and B. Olsen. 1999. Strategic use of information technology for increased innovation and performance. Information Management and Computer Security 7 (1): 5-22.

Jüttner, U. and H. Wehrli. 1994. Relationships marketing from a value system perspective. International Journal of Service Industry Management 5 (5): 54-73.

Kandampully, J. and R. Duddy. 1999. Relationship marketing: A concept beyond the primary relationship. Marketing Intelligence and Planning 17 (7): 315-323.

Karayanni, D. A. and G. A. Baltas. 2003. Website characteristics and business performance: Some evidence from international business-to-business organisations. Marketing Intelligence and Planning 21 (2): 105-114.

Kitchen, P. J. 1996. Public relations in the promotional mix: A three-phase analysis. Marketing Intelligence and Planning (14) 2:5-12.

Kitchen, P. J. and I. C. Papasolomou. 1997. Marketing public relations: Conceptual legitimacy or window dressing? Marketing Intelligence and Planning 15 (2 and 3): 71-85.

LaMonica, M. 1999. Stuck in the Web: Don't leave customers hanging while you untangle your online customer service. InfoWorld 21 (2). General BusinessFile Internat=l (accessed 20 March 2002).

Law, M., T. Lau and Y. H. Wong. 2003. From customer relationship management to customermanaged relationship: Unravelling the paradox with a co-creative perspective. Marketing Intelligence and Planning 21 (1): 5.1-60.

Markette, M. 2001. Plugging into through online. Customer Interaction Solutions, October:38-40.

Marks, W. B. 2002. Recovery through trust. Lecture presented at the Second Annual Leadership Conference of the Marketing Summit, Atlanta, Georgia, May 23 Business Source Premier (accessed 13 August 2002).

McKeown, B. and D. Thomas. 1988. Q methodology. Series: Quantitative applications in the social sciences. California: Sage.

Merrilees, B. and M. Fry. 2003. E-trust: The influence of perceived interactivity on e-retailing users. Marketing Intelligence and Planning 21 (2): 123-128.

Nielsen, J. 2001. Corporate Websites get a 'D' in PR. http://www.useit.com/alertbox/20010401.html (accessed 29 July 2002). 
Perry, M. and C. Bodkin. 2000. Content analysis of Fortune 100 company Websites. Corporate Communications: An International Journal 5 (2): 87-96.

Rowley, J. 1998. Promotion and marketing communications in the information marketplace. Library Review 47 (8): 383-387.

Sampson, S. E. 1998. Gathering customer feedback via the Internet: Instruments and prospects. Industrial Management and Data systems 98 (2): 71-82.

Simons, T. 2002. Behavioral integrity: The perceived alignment between managers' words and deeds as a research focus. Organization Science 13 (1), January-February: 18-35.

Steelman, T. A. and L. A. Maguire. 1999. Understanding participant perspective: Q methodology in National Forest Management. Denver: University of Colorado. http://www.env.duke.edu' people/faculty/maguire/env316/q5.htm (accessed 12 May 2004).

Sterne, J. 2000. Customer service on the Internet: Building relationships, increasing loyalty and staying competitive. 2nd ed. New York: Wiley.

Stricklin, M. and R. Almeida. 1999. PCQSoftware Manual. http://www.PCQWin $\backslash$ Helplindex.htm (accessed 10 December 2002).

Svensson, G. 2001. Extending trust and mutual trust in business relationships towards a synchronised trust chain in marketing channels. Management Decision 39 (6): 431-440.

Swift, T. 2001. Trust, reputation and corporate accountability to stakeholders. Business Ethics: $A$ European Review 10 (1): 16-26.

Treminio, A. 2000-2001. Customer management: The importance of online customer service. Technological Edge 45-46.

Wells, W., J. Burnett and S. Moriarty. 2003. Advertising principles and practice. 6th ed. New Jersey: Prentice-Hall.

Wells, B. and N. Spinks. 1999. Communicating with the community. Career Development International 4 (2): 108-116. 